\title{
PERLINDUNGAN HUKUM PEKERJA ANAK DI INDONESIA PASCA DIBERLAKUKANNYA UNDANG- UNDANG NO. 35 TAHUN 2014 TENTANG PERUBAHAN ATAS UNDANG-UNDANG NO. 23 TAHUN 2002 TENTANG PERLINDUNGAN ANAK
}

\author{
Sri Karyati \\ Fakultas Hukum Universitas Islam Al-Azhar \\ Jl. Unizar, Turida, Sandubaya, Kota Mataram \\ Indonesia \\ Telp (0370) 6175565 \\ Email: srikaryati84@gmail.com
}

\begin{abstract}
Abstrak
Fenomena pekerja anak yang terjadi di Indonesia saat ini, seperti menjadi suatu pemandangan yang sangat biasa. Peningkatan jumlah pekerja anak di Indonesia, merupakan permasalahan yang cukup genting untuk segera diupayakan suatu solusi baik oleh Pemerintah maupun pihak-pihak yang terkait. Ketentuan Undang-Undang Nomor 13 Tahun 2003 tentang Ketenagakerjaan, disebutkan bahwa pekerja anak adalah anak-anak yang berusia di bawah 18 tahun, hal ini sama sekali belum mengakomodir bagi perlindungan pekerja anak yang rata-rata berusia di bawah 18 tahun yang artinya tidak termasuk dalam pengertian anak dalam Undang-Undang Ketenagakerjaan yang berlaku. Hal ini perlu pengkajian lebih lanjut dari aspek hukum ketenagakerjaan, khususnya terkait perlindungan dari kerangka hukum ketenagakerjaan terhadap pekerja anak. Perlindungan bagi pekerja anak di Indonesia semestinya mengalami peningkatan dengan adanya UU No. 23 Tahun 2002 tentang Perlindungan Anak. Hal ini perlu dikaji lebih lanjut untuk mengetahui efektifitas dari hadirnya UU Ketenagakerjaan dan UU Perlindungan Anak terhadap kondisi pekerja anak di Indonesia. Dalam kajian ini penulis merumuskan permasalahan sebagai berikut, pertama; bagaimanakah peran pemerintah dalam upaya perlindungan pekerja anak di Indonesia?, kedua; faktor-faktor apakah yang dapat menghambat upaya perlindungan pekerja anak di Indonesia? Model perlindungan terhadap pekerja anak perlu dilakukan secara terpadu antar sektor di pusat dan daerah sebagai upaya pengganti dari tidak mungkin berjalannya upaya penghilangan angka pekerja anak di indonesia. Menurut penulis, Pemerintah diharapkan mampu menjadi penggerak sekaligus pelaksana program pengentasan angka keluarga miskin di Indonesia. Dalam upaya perlindungan pekerja anak di Indonesia, Pemerintah harus menentukan skala prioritas.
\end{abstract}

Kata Kunci: Pekerja Anak; Perlindungan Hukum.

\section{A. PENDAHULUAN}

Selama krisis ekonomi di Indonesia, berbagai media memberitakan secara luas terjadinya pengangguran. Berita itu menjadi besar, karena pengangguran terjadi dibanyak tempat dan serentak. Pertumbuhan angkatan kerja yang membesar namun tidak dibarengi penyediaan kesempatan kerja, merupakan salah satu faktor pemicu mengapa tingkat pengangguran bertambah dengan pesat. Pertumbuhan penduduk dan laju angkatan kerja, memang ibarat dua sisi mata uang yang tak dapat dipisahkan. Atau ibarat hidup secara simbiosis mutualisme, saling memetik manfaat dalam hal penduduk dan angkatan kerja, manfaat yang dipetik bisa positif, bisa pula negatif.

Jumlah penduduk Indonesia saat ini mencapai sekitar 213,72 juta, di mana jumlah penduduk usia kerja sebanyak 152,65 juta dengan jumlah angkatan kerja 100,31 juta. Dari jumlah diatas, sebanyak 90,78 juta bekerja dan 9,53 juta menganggur. Pertambahan angkatan kerja secara alami setiap tahun diperkirakan 1,6 juta-2,4 juta, sehingga dengan pertumbuhan ekonomi yang 
masih rendah $(4,5-5,4 \%)$ jumlah penganggur diperkirakan masih terus bertambah, karena terbatasnya kesempatan kerja yang dapat diciptakan dan banyaknya $\mathrm{PHK}^{1}$.

Kenaikan harga BBM di dalam negeri akhir tahun 2005 menyebabkan laju inflasi yang tinggi dan mendorong kenaikan suku bunga perbankan. Pada awal tahun 2006 terlihat kecenderungan perlambatan pertumbuhan ekonomi Indonesia, hal ini selain meningkatkan tekanan biaya hidup kepada masyarakat, juga mempengaruhi kemampuan perusahaan untuk tetap bertahan menjalankan usahanya. Untuk mengefisienkan usahanya, perusahaan pun melakukan pembatasan pekerjaan sampai pada keputusan yang tidak banyak disukai, yaitu pemutusan hubungan kerja (PHK). Gejala PHK ini merupakan salah satu faktor yang menyebabkab makin meningkatnyajumlah anak-anak yang bekerja, dan memperbesar angka pengangguran dan menurunkan daya beli masyarakat. Fenomena pekerja anak yang terjadi di Indonesia saat ini, seperti menjadi suatu pemandangan yang sangat biasa. Tidak sulit menemukan anak yang bekerja untuk memenuhi kebutuhan keluarganya.

Pekerja anak adalah sebutan yang lebih santun daripada buruh anak. ${ }^{2}$ Namun penyebutan yang lebih santun ini tidak mengurangi beban masalah yang dihadapi anak-anak yang terpaksa bekerja. Pengamatan visual dalam keseharian utamanya di perkotaan, menunjukkan banyaknya anakanak di bawah umur yang bekerja mencari nafkah di jalanan yang jumlahnya semakin meningkat dari waktu ke waktu. Mereka berjualan koran, mengamen, mengemis, menyemir sepatu serta bentuk usaha lain dalam memperoleh uang secara cepat. Secara empiris juga mengindikasikan peningkatan pekerja anak di sektor informal ini beberapa di antaranya bekerja dalam kondisi yang sangat berisiko yaitu dengan mencari sisa makanan dan pemungut sampah (pemulung)

\footnotetext{
${ }^{1}$ Rencana Strategis Departemen Tenaga Kerja dan Transmigrasi Tahun 2005-2009.

2 Abu Huraerah, Child Abuse (Kekerasan Terhadap Anak), Nuansa, Bandung, 2007, hlm. 80.
}

dan di atas jermal perikanan di lepas pantai. Kelompok yang pertama, utamanya banyak dilihat di perkotaan, tetapi kelompok terakhir banyak terdapat di daerah pesisir pantai di luar Jawa.

Secara konstitusional, setiap warga negara bersamaan kedudukannya didalam hukum dan pemerintahan tanpa ada kecuali. Kesamaan derajat di hadapan hukum tersebut merupakan asas hukum dalam melakukan hubungan antara para subjek hukum. Sehingga untuk mengatasi permasalahan yang mungkin timbul di antara subjek hukum tersebut pemerintah turut serta dengan mengeluarkan peraturan perundang-undangan dan peraturan pelaksanaan lainnya. Indonesia adalah Negara Hukum, hal tersebut sudah terdapat dalam konstitusi Undang-Undang Dasar Negara Republik Indonesia 1945 yaitu pada Pasal 1 ayat (3) yang berbunyi "Negara Indonesia adalah negara hukum". Dalam konstitusi kita Undang-Undang Dasar 1945 pasal 28B ayat (2) berbunyi: Setiap anak berhak atas kelangsungan hidup, tumbuh, dan berkembang serta berhak atas perlindungan dari kekerasan dan diskriminasi.

Peningkatan jumlah pekerja anak di Indonesia, merupakan permasalahan yang cukup genting untuk segera diupayakan suatu solusi baik oleh Pemerintah maupun pihak-pihak yang terkait. Dalam kebijakan aspek ketenagakerjaan, berdasarkan data sejak tahun 1995, Indonesia tidak mampu membendung bukan saja jumlah pekerja anak yang meningkat pesat, tetapi dampak sosial yang menggejala bahkan tidak tersentuh oleh kebijakan dan program aksi. Berdasarkan data Depnakertrans, pada tahun 1995 jumlah pekerja anak mencapai 1644 juta jiwa, meningkat menjadi 1768 juta jiwa (1996), menjadi 1802 juta jiwa (1997) dan mencapai 2183 juta jiwa (1998). Sedangkan menurut BPS (2000) jumlah pekerja anak mencapai 2,3 juta jiwa ${ }^{3}$.

Data tersebut di atas perlu mendapat perhatian karena dapat memicu hambatan

${ }^{3}$ http://www.bps.go.id/angka/ diakses pada tanggal 26 Desember 2018 
dinamika proses pembangunan SDM di masa depan. Dampaknya sangat besar, utamanya social cost yang diderita pekerja anak dan hilangnya kesempatan untuk memasuki dunia sekolah. Selain itu makin banyaknya pekerja anak atau di bawah umur, membuka peluang untuk eksploitasi tenaga anak-anak. Mereka tidak mengetahui hak-haknya sebagai pekerja, seperti hak cuti, klaim asuransi dan sebagainya yang terkait dengan peningkatan kesejahteraannya. Tingkat upah yang diterima relatif di bawah rata-rata upah pekerja dewasa, meski produktifitasnya melebihi pekerja dewasa, sehingga tidak mencerminkan beban kerja yang mereka lakukan.

Ketentuan Undang-Undang Nomor 13 Tahun 2003 tentang Ketenagakerjaan, disebutkan bahwa pekerja anak adalah anak-anak yang berusia di bawah 18 tahun, hal ini sama sekali belum mengakomodir bagi perlindungan pekerja anak yang ratarata berusia di bawah 18 tahun yang artinya tidak termasuk dalam pengertian anak dalam Undang-Undang Ketenagakerjaan yang berlaku. Hal ini perlu pengkajian lebih lanjut dari aspek hukum ketenagakerjaan, khususnya terkait perlindungan dari kerangka hukum ketenagakerjaan terhadap pekerja anak.

Meskipun dalam konsep hukum perjanjian, untuk melaksanakan suatu hubungan hukum antara para pihak yang berkepentingan, kepadanya diberikan kebebasan ${ }^{4}$ untuk membuat apa saja, kapan saja sepanjang tidak melanggar kesusilaan dan ketertiban umum. Dengan perkataan lain memberikan kebebasan yang seluas-luasnya kepada warga negara untuk mengadakan perjanjian yang berisi apa saja dan dalam bentuk apa saja, sepanjang tidak melanggar undang-undang, ketertiban umum dan kesusilaan ${ }^{5}$, namun hal ini tidak lantas memberikan kebebasan pagi pengusaha untuk mengadakan perjanjian kerja atau kontrak kerja bagi anak-anak.

Perlindungan bagi pekerja anak di Indonesia semestinya mengalami peningkatan

\footnotetext{
${ }^{4}$ Lihat pasal 1338 KUHPerdata.

5 Subekti, Hukum Perjanjian, Intermasa, Jakarta, 1979 , hlm. 13.
}

dengan adanya UU No. 23 Tahun 2002 tentang Perlindungan Anak. Hal ini perlu di kaji lebih lanjut untuk mengetahui efektifitas dari hadirnya UU Ketenagakerjaan dan UU Perlindungan Anak terhadap kondisi pekerja anak di Indonesia.

Berdasarkan uraian pada latar belakang diatas, maka penulis merumuskan permasalahan sebagai berikut:

1. Bagaimanakah peran pemerintah dalam upaya perlindungan pekerja anak di Indonesia?

2. Faktor-faktor apakah yang dapat menghambat upaya perlindungan pekerja anak di Indonesia?

Dari perumusan masalah penelitian tersebut, diharapkan nantinya akan tergambar dengan jelas upaya pemerintah dalam melindungi pekerja anak di Indonesia, serta faktor-faktor yang menghambatnya.

\section{B. METODE PENELITIAN}

Penelitian yang dilakukan adalah penelitian hukum normatif (normative legal research), yaitu penelitian yang dilakukan dengan cara mengkaji peraturan perundang-undangan yang berlaku atau diterapkan terhadap suatu permasalahan tertentu.

\section{PEMBAHASAN}

\section{Prinsip Perlindungan Pekerja Anak}

Undang-Undang Nomor 35 Tahun 2014 tentang Perlindungan Anak Undang-Undang tentang perlindungan anak ini di tetapkan pada tahun 2002, empat belas tahun setelah Indonesia menyatakan meratifikasi konvensi hak anak. Lamanya rentang waktu ini terlihat kurang seriusnya pemerintah untuk benarbenar melakukan perlindungan terhadap hak-hak anak. Pasal 3 menyebutkan bahwa Perlindungan anak bertujuan anak untuk menjamin terpenuhinya hak-hak anak agar dapat hidup tumbuh berkembang, dan berpartisipasi secara optimal sesuai harkat martabat kemanusiaan, serta mendapat 
perlindungan dari kekerasan dan diskriminasi, demi terwujudnya anak Indonesia yang berkulitas, berakhlak mulia, dan sejahtera. Bertitik tolak dari konsepsi perlindungan anak yang utuh, menyeluruh, dan komprehensif, undang-undang perlindungan anak ini meletakkan kewajiban memberikan perlindungan kepada anak berdasarkan asasasas yaitu:

1. Asas dan prinsip non diskriminasi; Artinya semuahakyangdiakuidanterkandungdalam Konvensi Hak Anak harus diberlakukan kepadasetiapanaktanpapembedaanapapun. Prinsip ini ada dalam pasal 2 ayat (1) : "Negara-negara pihak menghormati dan menjamin hak-hak yang ditetapkan dalam konvensi ini bagi setiap anak yang berada di wilayah hukum mereka tanpa diskriminasi dalam bentuk apapun, tanpa memandang ras, warna kulit, jenis kelamin, bahasa, agama, pandangan politik, atau pandanganpandangan lain, asal-usulkebangsaan, etnik atau sosial, status kepemilikan, cacat atau tidak, kelahiran atau status lainnya baik dari anak itu sendiri atau dari orang tua walinya yang sah." Ayat (2): 'Negara-negara pihak akan mengambil semua langkah yang perlu untuk menjamin agar anak dilindungi dari semua langkah yang perlu untuk menjamin agaranakdilindungidarisemuadiskriminasi atau hukuman yang didasarkan pada status, kegiatan, pendapat yang dikemukakan atau keyakinan dari orang tua anak, walinyayang sah atau keluarganya."

2. Asas dan prinsip kepentingan yang terbaik bagi anak (Best Interst Of The Child); Prinsip ini tercantum dalam pasal 3 ayat (1) berbunyi : "dalam semua tindakan yang menyangkut anak yang dilakukan lembaga-lembaga kesejahteraan sosial pemerintah maupun swasta, lembaga peradilan, lembaga pemerintah atau badan legislative, maka kepentingan yang terbaik bagi anak harus menjadi pertimbangan utama. Prinsip ini mengingatkan kepada semua penyelenggaraan perlindungan anak bahwa pertimbangan-pertimbangan dalam Pengambilan keputusan apalagi berpusat kepada kepentingan orang dewasa. Apa yang menurut orang dewasa baik, belum tentu baik pula menurut ukuran kepentingan anak. Boleh jadi maksud dan tujuan orang dewasamemberikanbantuandanmenolong, akantetapiyangsesungguhnyaterjadiadalah penghancuran masa depan si anak.

3. Asas dan prinsip hak untuk hidup, kelangsungan hidup, dan perkembangan (The Right To Life, Survival, And Development); Prinsip ini tercantum dalam pasal6KHAayat(1):"Negara-negara pihak mengakui bahwa setiap anak memiliki hak yang melekat atas kehidupan." Ayat (2) : "Negara-negara pihak akan menjamin sampai batas maksimal kelangsungan hidup dan perkembangan anak." Pesan dari prinsip ini sangat jelas bahwa Negara harus memastikan setiap anakakan terjamin kelangsungan hidupnya karena hak hidup adalah sesuatu yang melekat dalam dirinya, bukan pemberian dari negara atau orangperorangan. Untuk menjamin hak hidup tersebut berarti negara harus menyediakan lingkungan yang kondusif, sarana, dan prasarana hidup yang memadai, serta akses setiap anak untuk memperoleh kebutuhankebutuhan dasar.

4. Asas dan prinsip penghargaan terhadap pendapat anak (Respect For The Views Of TheChild); Prinsipiniadadalampasal12ayat (1) KHA, berbunyi : "Negara-negara pihak akanmenjaminanak-anakyangmempunyai pandangan sendiri memperoleh hak menyatakan pandangan-pandangan secara bebas dalam semuahalyang mempengaruhi anak, dan pandangan tersebut akan dihargai sesuaidengantingkatusiadankematangan." Prinsip ini menegaskan bahwa anak memiliki otonomi kepribadian. Oleh karena itu, dia tidak biasa hanya dipandang dalam posisi yang lemah, menerima, dan pasif tetapi sesungguhnya dia pribadi otonom yang memiliki pengalaman, keinginan, imajinasi, obsesi, dan aspirasi yang belum tentu sama dengan orang dewasa. FaktorFaktoryang melatarbelakangi PekerjaAnak Keterlibatan anak dalam faktor produktif 
sesungguhnya bukan sekedar karena motifmotif ekonomi saja. Melainkan juga karena kebiasaan dan faktor kultural. Pada daerah pedesaan dan umumnya, terlebih lagi dalam lingkungan keluarga, kebiasaan untuk melibatkan anak dalam kegiatan kerja, baik dirumahatau diluarrumah sebagailife circle seorang anak. Sebagai suatu keharusan dan proses yang mesti dilalui sebelum beranjak dewasa memasuki kehidupan rumah tangganya kelak.

\section{Peran Pemerintah Dalam Perlindungan Pekerja Anak}

Anak sebagai makhluk Tuhan Yang Maha Esa memiliki hak asasi atau hak dasar sejak dilahirkan, sehingga tidak ada manusia atau pihak lalin yang merampas hak tersebut. Salah satu bentuk hak dasar anak adalah jaminan untuk tumbuuh kembang secara utuh, baik fisik maupun mental. Jaminan perlindungan hak dasar tersebut sesuai dengan nilai-nilai Pancasila dan tujuan negara sebagaimana tercantum dalam Pembukaan UndangUndang Dasar $1945 .^{6}$

Berkaitan dengan perlindungan pekerja anak, Pemerintah dapat berperan melalui berbagai kebijakan yang dapat dikeluarkan dan hingga saat ini telah dikeluarkan berbagai kebijakan oleh Pemerintah dalam rangka memberikan perlindungan bagi pekerja anak. Ketentuan yang mengakomodir tentang perlindungan bagi pekerja anak adalah; Undang-Undang No. 13 Tahun 2003 tentang Ketenagakerjaan, yang mengatur mengenai pekerja anak dalam ketentuan Pasal 68 sampai Pasal 75. Selain itu, Pemerintah juga menetapkan suatu Undang-Undang No.35 tahun 2014 tentang perubahan Undang-undang No.23 Tahun 2002 tentang Perlindungan Anak yang banyak memberikan ruang pada upaya perlindungan anak secara umum dan pada ketentuan perubahannya mengatur mengenai perlindungan terhadap anak dari kejahatan seksual serta perlindungan bagi anak penyandang disabilitas. Melalui

\footnotetext{
6 Penjelasan Umum UU No. 20 Tahun 1999 tentang Pengesahan ILO Convention No. 138 Concerning Minimum Age For Admission.
}

Undang-Undang ini pula, kemudian terbentuk suatu Komisi Perlindungan Anak Indonesia, kemudian ditetapkan Undang-Undang No. 20 tahun 1999 untuk ratifikasi konvensi ILO No. 138 tahun 1973, tentang Usia Minimun untuk Diperbolehkan Bekerja, serta ratifikasi konvensi ILO no. 182, tentang Pelarangan dan Tindakan Segera untuk Penghapusan Bentuk-Bentuk Pekerjaan Terburuk untuk Anak, melalui Undang-Undang No. 1 tahun 2000. Ketentuan Undang-Undang Nomor 35 tahun 2014 tentang perubahan atas UndangUndang Nomor 23 tahun 2002 tentang Perlindungan Anak mempertegas tentang perlunya pemberatan sanksi pidana dan denda bagi pelaku kejahatan anak terutama kepada kejahatan seksual yang bertujuan untuk memberikan efek jera, serta mendorong adanya langkah konkrit untuk memulihkan kembali fisik, psikis dan social anak. Hal tersebut perlu dilakukan untuk mengantisipasi anak (korban kejahatan) dikemudian hari tidak menjadi pelaku kejahatan yang sama..

Pemerintah juga berperan untuk kembali menggalakkan program wajib belajar bagi anak-anak yang bekerja, sehingga wawasan dan ketrampilan pekerja anak dapat terus ditingkatkan baik belajar secara formal maupun non formal dengan pelatihan ketrampilan tertentu sehingga anak meskipun harus bekerja tidak kehilangan haknya untuk mendapatkan pendidikan.

Namun peran pemerintah dalam upaya perlindungan bagi pekerja anak terutama dalam perlindungan hukumnya, Stephen J. Woodouse $^{7}$ berpendapat bahwa sistem hukum dan perundang-undangan di Indonesia terkesan kurang tanggap dan bahkan dalam masyarakat sendiri muncul pandangan bahwa anak yang bekerja dianggap sebagai suatu bentuk latihan dan pengabdian anak kepada orang tua, sehingga hal ini bukanlah suatu permasalahan yang serius. Sehingga peranan Pemerintah yang sangat strategis bagi perlindungan pekerja anak tidak dapat berlaku

\footnotetext{
${ }^{7}$ Stephen Woodouse, Implementasi Konvensi Hak Anak dalam Hukum Pekerja Anak Di Indonesia, Makalah pada Konferensi Nasional tentang Perlindungan Hukum Pekerja Anak di Indonesia, tanggal 27-28 Nopember 1998, Cairo.
} 
secara efektif. Paradigma yang berkembang dimasyarakat ini harus diiringi dengan aktifnya Pemerintah dalam mensosialisasikan program wajib belajar bagi anak usia sekolah.

\section{Hambatan Dalam Perlindungan Pekerja Anak}

Dalam kebijakan yang sudah ada, Pemerintah terlihat kurang bersungguhsungguh dalam implementasi peraturan. Ratifikasi konvensi ILO No. 138 tahun 1973, tentang Usia Minimun untuk Diperbolehkan Bekerja, melalui Undang-Undang No. 20 tahun 1999. Kemudian konvensi ILO no. 182, tentang Pelarangan dan Tindakan Segera untuk Penghapusan Bentuk-Bentuk Pekerjaan Terburuk untuk Anak, melalui UU No. 1 tahun 2000 seharusnya membawa perubahan yang signifikan terhadap pengurangan jumlah pekerja anak, namun pemerintah pada prakteknya masih kewalahan dalam penerapan sanksi atas pelanggaran hukum menurut peraturan perundang-undangan di atas. Hal ini merupakan kendala kedua setelah sulitnya mengukur adanya penyimpangan sosial atas keberadaan pekerja anak di banyak perusahaan.

Identifikasi yang transparan tentang keberadaan pekerja anak di suatu perusahaan pun, banyak mengalami kendala. Biasanya anak mempunyai keinginan untuk bekerja atas kemauan sendiri, sehingga dapat diduga mereka menaikkan usia pada saat mendaftar menjadi pekerja agar dapat diterima, sangatlah mungkin. Hal-hal seperti ini menjadi salah satu faktor, mengapa sanksi atas pelanggaran hukum berdasarkan peraturan yang sudah ada, condong tidak pernah terjadi. ${ }^{8}$

Keberadaan pekerja anak di semua daerah (desa dan kota) memunculkan dikotomi pendapat pro dan kontra. Beberapa pihak mengatakan, bahwa dengan pekerja anak mereka memberikan sesuatu (bekerja) kepada perusahaan di samping memperoleh upah yang layak untuk mengurangi beban ekonomi keluarga. Munculnya pekerja anak

\footnotetext{
8 http://www.menegpp.go.id/menegpp.php?cat=detail\&id $=$ media\&dat $=579$, diakses tanggal 20 desember 2018.
}

berangkat dari kemiskinan keluarga dalam upaya mencari tambahan pendapatan dan keberlangsungan kehidupan keluarga.

Di Indonesia, upaya menghapus pekerja anak merupakan kebijakan yang pada dasarnya dapat ditempuh oleh Pemerintah dalam penanggulangan pekerja anak maupan upaya perlindungan pekerja anak, dipersepsikan sebagai kebijakan yang tidak logis, karena tidak saja menghapus kesempatan anak untuk memperoleh uang sendiri, tetapi lebih jauh akan mengganggu kondisi ekonomi keluarga miskin yang kenyataannya di Indonesia jumlahnya semakin banyak. Selama demand pekerja anak yang di-supply oleh keluarga miskin semakin meningkat, maka selama itu pulalah pelarangan terhadap pekerja anak justru ditakutkan akan memicu terjadinya black market terhadap pekerja anak. ${ }^{9}$

Persepsi yang berkembang di masyarakat yang dapat menjadi suatu hambatan dalam upaya perlindungan pekerja anak, antara lain persepsi sebagai berikut ${ }^{10}$ :

1. Pendidikan formal yang dilaksanakan kerapkali tidak sesuai dengan kebutuhan anak keluarga miskin dan bahkan menjauhkan kebutuhan anak keluarga miskin dan bahkan menjauhkan mereka dari lingkungannya;

2. Anak diperlukan untuk ikut membantu memenuhi kebutuhan keluarga, terutama bagi keluarga miskin;

3. Undang-undang dan peraturan mengenai pekerja anak sulit dilaksanakan karena banyaknya perusahaan yang memperkerjakan anak;

4. Anggapan bahwa pemerintah tidak seharusnya mencampuri kenginan orang tua tentang apa yang dirasakannya paling baik bagi anak-anak mereka sendiri.

\section{Alternatif Perlindungan Pekerja Anak}

Upaya perlindungan terhadap pekerja anak perlu dilakukan secara terpadu antar sektor di pusat dan daerah sebagai upaya pengganti

\footnotetext{
http://www.nakertrans.go.id/majalah_buletin/ warta naker/edisi 7/data pekerja anak.php, diakses tanggāl 28 desember $201 \overline{8}$.

${ }^{10}$ Abu Huraerah, Child Abuse...Op. Cit., hlm. 83-84.
} 
dari tidak mungkin berjalannya upaya penghilangan angka pekerja anak di indonesia. Perlindungan pekerja anak merupakan upaya pemerintah untuk "melarang" pekerja anak dan mengharapkan semua anak usia sekolah dapat mengembangkan intelektualitasnya di sekolah untuk mendapatkan sumber daya manusia yang bermutu di masa depan.

Namun pemerintah tidak dapat menghindar dari kenyataan bahwa masih tingginya angka keluarga miskin di Indonesia, sehingga mengijinkan anak-anak yang bekerja bahkan harus bekerja. Pada intinya pengentasan pekerja anak ini diupayakan melalui akarnya, yaitu dari sisi keluarga, yakni keluarga miskin.

Menurut penulis, perlindungan dari sisi ini merupakan alternatif yang cukup mahal, khususnya bagi pemerintah yang diharapkan mampu menjadi penggerak sekaligus pelaksana program pengentasan angka keluarga miskin di Indonesia, antara lain misalnya dengan Program Tabungan Keluarga Sejahtera atau Program Kredit Usaha Keluarga Sejahtera. Program tersebut di atas merupakan upaya yang dapat dilakukan Pemerintah untuk melakukan pemulihan ekonomi masyarakat. Upaya ini merupakan suatu alternatif untuk mengurangi, menanggulangi sekaligus melindung potensi pekerja anak dengan memberikan kemampuan ekonomi pada orang tuanya. Sehingga tidak lagi ada kewajiban bekerja yang melekat pada anak-anak, karena dari sisi permintaan, perusahaan yang mempekerjakan anak-anak antara lain karena upah yang lebih murah, biaya produksi lebih sedikit, usia mereka relatif muda sehingga sangat mudah diatur, tidak banyak menuntut seperti pekerja dewasa yang disebabkan oleh ketidakmampuan ekonomi orang tua.

Selain itu menurut penulis alternatif lain yang dapat diberlakukan dalam rangka perlindungan pekerja anak adalah konsistensi dari pemerintah dalam hal pendidikan dan keterampilan bagi anak. Pemerintah harus menyediakan sarana pendidikan berkualitas, sekaligus terjangkau oleh keluarga miskin, bebas biaya bagi keluarga miskin dengan sistem subsidi silang dan tanpa sistem administrasi yang memberatkan keluarga miskin. Diharapkan dengan masuk sekolah akan mengurangi waktu mereka untuk bekerja dan mengurangi peluang orang tua dalam memaksa mereka untuk bekerja. Justru dengan sekolah nantinya akan menambah pengetahuan dan keterampilan dalam bersaing di dunia kerja. ${ }^{11}$

Namun dengan berbagai alternatif perlindungan bagi anak maupun pekerja anak tersebut diatas, pada dasarnya bukan suatu proses yang dapat teratasi seperti membalikkan telapak tangan. Diperlukan proses secara bertahap khususnya untuk mengubah persepsi masyarakat mengenai kewajiban anak untuk bekerja membantu perekonomian keluarga.

\section{KESIMPULAN}

Dalam perlindungan pekerja anak, pemerintah mempunyai peran yang strategis. Dalam hal ini pemerintah berperan sebagai aktor regulasi dengan meratifikasi konvensi internasional dan menetapkan peraturan perundang-undangan yang bertujuan untuk melindungi anak dan pekerja anak di Indonesia.

Hambatan-hambatan dalam upaya perlindungan pekerja anak adalah sebagai berikut:

a. Tidak transparannya pengusaha dalam memberikan laporan pekerja anak yang bekerja di perusahaannya;

b. Persepsi masyarakat mengenai keberadaan pekerja anak yang merupakan suatu kewajiban;

c. Masih tingginya tingkat penduduk miskin di Indonesia;

d. Masih lemahnya komitmen pemerintah dalam perlindungan pekerja anak.

Dalam upaya perlindungan pekerja anak di Indonesia, pemerintah harus menentukan ${ }^{11}$ http://www.nakertrans.go.id/majalah_buletin/
majalah_balitfo/volume_2_4/implikasi\%20_pening-
katan.php., diakses pada tanggal 28 desember 2018 . 
skala prioritas. Untuk saat ini ada 2(dua) cara yang dapat ditempuh pemerintah, yakni:

1. Menurut penulis pemerintah sebaiknya fokus pada upaya pengentasan kemiskinan dengan cara peningkatan ekonomi masyarakat sehingga anak-anak dari kalangan ekonomi rendah tidak lagi berkewajiban membantu ekonomi orangtuanya dan mendapatkan hak-haknya sebagai anak;

2. Pemerintah secara konsisten menjalankan program wajib belajar bagi anak usia sekolah dan bagi keluarga ekonomi rendah dibebaskan dari biaya.

\section{DAFTAR PUSTAKA}

\section{Buku}

Abu Huraerah. Child Abuse (Kekerasan Terhadap Anak). Bandung: Nuansa. 2007.

Abdul Khakim. Pengantar Hukum Ketenagakerjaan Indonesia. Bandung: Citra Aditya Bakti. 2007.

Soetarso. Praktek Pekerjaan Sosial. Bandung: Sekolah Tinggi Kesejahteraan Sosial. 1998.

\section{Makalah, Artikel, Koran}

Rencana Strategis Departemen Tenaga Kerja dan Transmigrasi Tahun 2005-2009.

Stephen Woodhouse, Implementasi Konvensi Hak Anak dalam Hukum Pekerja Anak di Indonesia, Makalah pada Konferensi Nasional tentang Perlindungan Hukum Pekerja Anak di Indonesia, pada tanggal 27-28 Nopember 1998, Cairo.

\section{Referensi dari Internet}

http://www.nakertrans.go.id, diakses pada tanggal 28 Desember 2018.

http://www.menegpp.go.id, diakses pada tanggal 20 Desember 2018.

www.wikipediafoundation.org, diakses pada tanggal 28 Desember 2018.

\section{Peraturan Perundang-Undangan}

Undang-Undang Dasar Republik Indonesia 1945.

Undang-Undang Nomor 13 Tahun 2003 Tentang Ketenagakerjaan.

Undang-Undang No.35 Tahun 2014 tentang perubahan Undang-Undang No.23 Tahun 2002 tentang Perlindungan Anak.

Undang-Undang Nomor 20 Tahun 1999 tentang Pengesahan ILO Convention No. 138 Concerning Minimum Age For Admission (Usia Minimum Untuk Diperbolehkan Bekerja).

Undang-Undang Nomor 1 Tahun 2000 tentang Pengesahan Konvensi ILO No. 182 tentang Pelarangan dan Tindakan Segera untuk Penghapusan Bentuk-Bentuk Pekerjaan Terburuk untuk Anak.

Keputusan Presiden Nomor 59 Tahun 2002 tentang Rencana Aksi Nasional (RAN) Penghapusan Bentuk-Bentuk Pekerjaan Terburuk untuk Anak. 